\title{
Prematurity and Lecithin-Cholesterol Acyltransferase Deficiency in Newborn Infants
}

\author{
SUSHIL K. JAIN \\ Department of Pediatrics, Louisiana State University School of Medicine, Shreveport, Louisiana
}

\begin{abstract}
The occurrence of hyperlipidemia and fat accumulation in certain tissues of premature newborn infants is known. Lecithin-cholesterol acyltransferase (LCAT) catalyzes esterification of free cholesterol and is important in the transport and disposal of lipids. Cord plasma LCAT activity of full-term newborn infants is nearly one-half of that present in the adult plasma. The present study also has found a significant positive correlation between cord plasma LCAT activity and gestational age of the newborn. The rato of circulating cholesterol ester to free cholesterol was significantly lower only in newborn infants with gestational age less than $32 \mathrm{wk}$, in comparison to full-term newborn infants or adults. LCAT deficiency and decreased cholesterol ester formation may be responsible for the inadequate lipid clearance in premature newborn infants. (Pediatr Res 19: 58-60, 1985)
\end{abstract}

\section{Abbreviations}

LCAT, lecithin-cholesterol acyltransferase

TLC, thin-layer chromatography

HDL, high-density lipoproteins

VLDL, very low-density lipoproteins

Recent studies have reported occurrence of hyperlipidemia and fat accumulation in certain tissues of premature newborn infants $(1,2)$. This incidence is greater in infants given lipid emulsions (3-6). Lipid emulsions are widely used in infants when adequate calorie intake cannot be achieved by oral feeding. The role of LCAT in the regulation of lipid metabolism has been extensively studied (7-9). LCAT esterifies free cholesterol to a cholesterol ester, utilizing the $\beta$-fatty acid of the lecithin molecule. Deficiency of LCAT both in humans and experimental animals has been shown to be associated with hyperlipidemia and fat accumulation in the tissues (10-15). The present study has found that premature newborn infants are deficient in LCAT. It is suggested that LCAT deficiency is a factor responsible for the hyperlipidemia and fat accumulation observed in these infants.

Plasma LCAT activity was measured by quantitating the rate of esterification of $\left[{ }^{14} \mathrm{C}\right]$ cholesterol to $\left[{ }^{14} \mathrm{C}\right]$ cholesterol ester, and indirectly, by measuring the ratio of circulating esterified cholesterol to free cholesterol separated by TLC.

\section{MATERIALS AND METHODS}

Placental cord blood samples were utilized for the entire study, for which approval by the Medical Center Review Committee

Received May 1, 1984; accepted July 24, 1984.

Address for correspondence Sushil K. Jain, Ph.D., Department of Pediatrics, LSU Medical Center, 1501 Kings Hwy., Shreveport, LA 71130.

Supported in part by a grant-in-aid from Hofmann-LaRoche, Inc. and an Edward P. Stiles Award by the University. on Human Experimentation was obtained. Blood was collected into heparinized tubes within $4 \mathrm{~h}$ of delivery. Blood was centrifuged at $1000 \times g$ at $4^{\circ} \mathrm{C}$ for $10 \mathrm{~min}$. Plasma was aspirated with a Pasteur pipette and frozen at below $-10^{\circ} \mathrm{C}$. All analyses were performed on frozen plasma samples. Gestational age of newborn infants was obtained from the log book of the delivery room after completion of all determinations.

Plasma LCAT determinations. Substrate for LCAT was prepared by incubating $10 \mu \mathrm{Ci}$ of $4-\left[{ }^{14} \mathrm{C}\right]$ cholesterol (specific activity $59.4 \mathrm{mCi} / \mathrm{mmol}$; New England Nuclear, Boston, MA) with 10 $\mathrm{ml}$ of heat inactivated normal human plasma $\left(55^{\circ} \mathrm{C}\right.$ for $\left.30 \mathrm{~min}\right)$ in a shaking water bath for $3 \mathrm{~h}$. Heat inactivated plasma containing $\left[{ }^{14} \mathrm{C}\right]$ cholesterol was then centrifuged for $10 \mathrm{~min}$ at $15,000 \times$ $g$ in a refrigerated centrifuge, and the clear supernatant was used as substrate for enzyme assay (16). To 10-ml capacity glass tubes $200 \mu \mathrm{l}$ of substrate and $50 \mu \mathrm{l}$ of test plasma each were added. Control tubes contained only substrate. Tubes were incubated in a water bath at $37^{\circ} \mathrm{C}$ for $2 \mathrm{~h}$. At the end of incubation, the reaction was stopped by adding $2 \mathrm{ml}$ of methanol and mixing. Tubes were allowed to stand at room temperature for $15 \mathrm{~min}$ during which they were mixed at least three times. Then $2 \mathrm{ml}$ of chloroform were added, and tubes were allowed to stand at room temperature for another $15 \mathrm{~min}$ with intermittant mixing. The tubes were then centrifuged at $1000 \times g$ for $10 \mathrm{~min}$. The supernatant was then decanted into another $10-\mathrm{ml}$ glass tube and dried with a stream of nitrogen while keeping the tubes in a water bath at about $40^{\circ} \mathrm{C}$. The dried lipid extract was dissolved in 100 $\mu \mathrm{l}$ of chloroform. The free and esterified cholesterol in the lipid extract were separated by TLC on silica gel G plates (Brinkman Instruments, Inc., Westbury, NY) with a solvent system consisting of petroleum ether/ether/acetic acid (90:10:1, v/v) as described previously (17). On some plates, standard cholesterol and cholesterol ester were also spotted as a marker. After developing the TLC plate, it was dried and then exposed to iodine vapors to visualize cholesterol and cholesterol ester spots. Lipid spots were encircled with a needle or lead pencil. The plate was allowed to stay at room temperature for about $4 \mathrm{~h}$ or preferably overnight to get rid of iodine, which otherwise may cause quenching of radioactive counts. The free cholesterol and cholesterol ester spots were scraped into counting vials and $5 \mathrm{ml}$ of counting fluid was added (New England Nuclear). $\left[{ }^{14} \mathrm{C}\right]$ radioactivity was determined with a Beckman LS-250 liquid scintillation system.

Lipid extraction and quantitation. Plasma lipids were extracted by the method of Folch et al. (18), using the solvent system chloroform/methanol $(2: 1, \mathrm{v} / \mathrm{v})$. Cholesterol and cholesterol esters were separated as described above. Cholesterol was determined by the method Zlatkis et al. (19). Statistical analyses were carried out as described by Colton (20).

\section{RESULTS}

Figure 1 shows the plasma LCAT activity of adults and fullterm newborn infants. Plasma LCAT activity in the newborn infants is nearly one-half of that present in the adults. Similar 


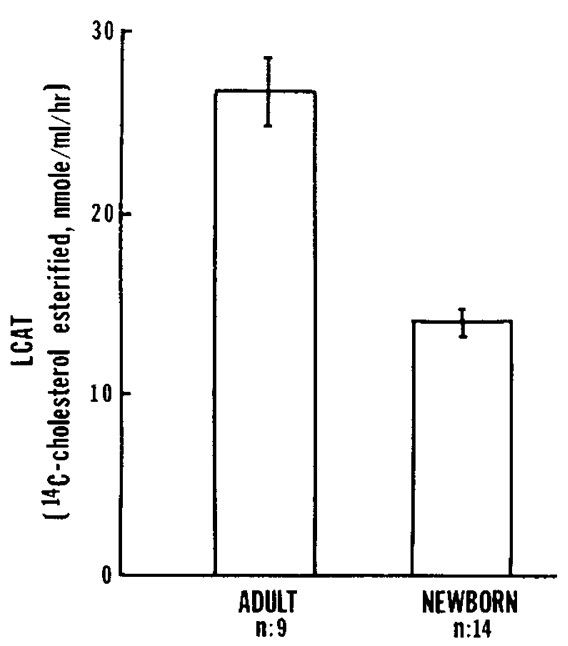

Fig. 1. Plasma LCAT activity in adult and full-term newborn infant cord blood. Values are mean \pm SE. $\mathrm{n}$ is the number of blood samples in that group. Differences in the values are statistically significant $(p<$ $0.001)$.

low levels of LCAT in the cord serum in comparison to adult serum has been reported by other investigators (21-23).

Figure 2 illustrates cord plasma LCAT activity of newborn infants at varying gestational ages. There is a decrease in LCAT activity in the premature infants. Both linear $(r=0.95)$ and parabolic $(r=0.99)$ regression analyses show that LCAT activity has a significant positive correlation with the gestational age of the newborn. From linear regression analysis, it seems that LCAT activity starts appearing in the blood at gestational age of $26 \mathrm{wk}$.

LCAT activity also was assessed indirectly by quantitating the ratio of esterified cholesterol to free cholesterol in the circulating plasma. Table 1 shows that this ratio is significantly lower in the plasma of infants born at gestational ages less than $32 \mathrm{wk}$, in comparison to full-term newborn infants or adults $(2.1 \pm 0.12)$.

\section{DISCUSSION}

The mechanism of LCAT action has been reviewed (7-9). LCAT catalyzes the formation of cholesterol esters in the HDL fraction. The cholesterol esters formed are then transferred from HDL to the VLDL fraction in exchange for triglycerides. Thus, LCAT is important in decreasing the unesterified cholesterol and triglycerides of VLDL and low-density lipoproteins in the plasma.

The present survey has shown that premature newborn infants are deficient in LCAT. The LCAT activity has a positive significant correlation with the gestational age of the newborn. However, the ratio of esterified cholesterol to free cholesterol was significantly lower only in infants with a gestational age of less than $32 \mathrm{wk}$. This latter finding is consistent with our previous study (16) on the plasma lipids of an hereditary LCAT-deficient family, containing both homozygous with zero LCAT activity and heterozygous members with half-normal LCAT activity, in which we observed a near absence of cholesterol ester in the homozygous individuals but nearly normal cholesterol ester/free cholesterol in the heterozygous individuals. The studies of hereditary LCAT deficiency and of newborn infants both suggest that a decrease in more than one-half of the normal adult levels of LCAT is required to disrupt the normal proportion of esterified cholesterol and free cholesterol in the plasma.

The finding of LCAT deficiency in premature newborn infants is of significance. On the 1 st day of life, with the sudden transfer from the carbohydrate diet of the fetus to the fat diet of extrauterine life, fat becomes a major energy source for the infant. In some infants, particularly premature infants, adequate calorie intake cannot be achieved orally because of respiratory or other complications. These infants are often given intravenous lipid

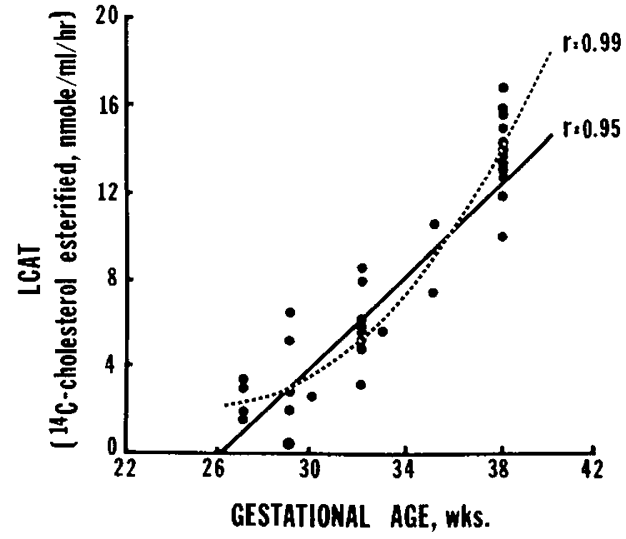

Fig. 2. Cord plasma LCAT activity of newborn infants born at different gestational ages. $r=$ correlation coefficient. Note the significant positive correlation between plasma LCAT activity and gestational age of the newborn infants.

Table 1. Esterified cholesterol/free cholesterol ratio in the cord plasma of newborn infants

\begin{tabular}{ccccl}
\hline \multirow{2}{*}{$\begin{array}{c}\text { Esterified } \\
\text { cholesterol/ } \\
\text { free }\end{array}$} & \multicolumn{4}{c}{ Gestational age (wk) } \\
\cline { 2 - 5 } cholesterol & $41-38$ & $37-32$ & $31-29$ & $28-27$ \\
\hline Mean & $1.96^{*}$ & 1.83 & $1.51 \dagger$ & $0.49 \dagger$ \\
$\mathrm{SE}$ & 0.10 & 0.06 & 0.11 & 0.09 \\
$n \ddagger$ & 10 & 12 & 8 & 6 \\
\hline
\end{tabular}

Differences between values ${ }^{*}$ and $\dagger$ are statistically significant $(p<$ $0.01)$.

$\ddagger$ Total number of blood samples in that group.

emulsions. Various investigators have shown that premature infants less than $32-33 \mathrm{wk}$ gestational age have poor clearance of lipid emulsions in comparison to less premature or term infants $(3-6,24-26)$. In addition, other studies have shown that some premature infants accumulate lipid in the tissues even if they are not given lipid emulsions $(1,2)$. The present findings suggest that deficiency of LCAT and reduced cholesterol ester formation in HDL may impair transport and disposal of cholesterol, triglycerides, and phospholipid, resulting in the hyperlipidemia and fat accumulation in the tissues of premature infants.

Premature infants have reduced ability to oxidize fatty acids (27), presumably due to low levels of carnitine (28). The role of low levels of postheparin lipoprotein lipase in the hyperlipidemia of premature infants given lipid emulsion also has been suggested $(25,29)$. Thus, inadequate lipid clearance in premature infants also could be due to the deficiency of any one of these lipid metabolizing enzymes. Exchange of triglycerides with cholesterol ester is essential for triglyceride release from the chylomicrons and subsequent hydrolysis to free fatty acids by lipoprotein lipase. Thus, plasma deficient in LCAT and cholesterol ester may not be optimal for the hydrolysis of triglycerides. Recently, Levene (30) has reported no relation between intrapulmonary fat accumulation and lipoprotein lipase activity in one of two premature infants who died after administration of fat emulsion. These indirect evidences suggest that LCAT deficiency might be crucial in the inadequate lipid metabolizing ability of newborn premature infants.

Acknowledgments. The author is grateful to Mrs. Ethelyn B. LaHaye for her technical assistance and to Mrs. Kathy Jones for typing.

\section{REFERENCES}

1. Aherne W 1965 Fat infiltration in the tissues of the newborn infant. Arch Dis Child 40:406 
2. Andersen GE, Hertel J, Tygstrup I 1981 Pulmonary fat accumulation in preterm infants. Lancet $1: 441$

3. Barson AJ, Chiswick M, Doig CM 1978 Fat embolism in infancy after intravenous fat infusions. Arch Dis Child 53:218

4. Barson AJ 1980 Safety of intralipid. Lancet 2:1021

5. Levene MI, Wigglesworth JS, Desai R 1980 Pulmonary fat accumulation after intralipid infusion in the preterm infant. Lancet $2: 815$

6. Dahms BB, Halpin TC 1980 Pulmonary arterial lipid deposit in newborn infants receiving intravenous lipid infusion. J Pediatr 97:800

7. Glomset JA, Norum KR 1973 The metabolic role of lecithin cholesterol acyltransferase: Prospective from pathology. Adv Lipid Res 11:1

8. Nicoll A, Miller NE, Lewis B 1979 High density lipoprotein metabolism. Adv Lipid Res 17:53

9. Shojania AM, Jain SK, Shohet SB 1983 Hereditary lecithin cholesterol acyltransferase deficiency: report of two new cases and review of the literature. Clin Invest Med 6:49

10. Stokke KT, Bjerve KS, Blomhoff JP, Oystese B, Flatmark A, Norum KR Gjone E Familial lecithin cholesterol acyltransferase deficiency: Study on lipid composition and morphology of tissues. Scand J Clin Lab Invest 137:93

11. Bron AJ, Lloyd JK, Fosbrooke AS, Winder AF, Tripathi RC 1975 Familia LCAT deficiency disease. Lancet 1:928

12. Frohlich J, Godolphin WJ, Reeve CE, Evelyn KA 1976 Familial LCAT deficiency: Report of two patients from a Canadian family of Italian and Swedish descent. Scand J Clin Lab. Invest 38(suppl) 150:156

13. Naito C, Teramoto T, Kato M, Watanabe T, Yamanaka T, Iwamoto A 1978 Lipid compositions of plasma major lipoproteins and lipoproteinlipase activity in hypolipidemic and hyperlipidemic siblings with familial LCAT deficiency. Scand J Clin Lab Invest 38(suppl) 150;168

14. Jain SK, Yip R, Pramanik AK, Dallman PR, Shohet SB 1982 Reduced plasma cholesterol esterifying activity in iron-deficient rats: Its possible role in the lipemia of iron deficiency. J Nutr 112:1230

15. Moorhead JF, El-Nahas M, Harry D, Persaud JW, Mayne K, Chan MK Verghese, Z 1983 Focal glomerular sclerosis and nephratic syndrome with partial lecithin: Cholesterol acyltransferase deficiency and discoidal high density lipoprotein in plasma and urine. Lancet 1:936

16. Jain SK, Mohandas N, Sensabaugh GF, Shojania AM, Shohet SB 1982 Hereditary lecithin-cholesterol acyltransferase deficiency: a heterozygous var- iant with erythrocyte membrane abnormalities. J Lab Clin Med 99:816

17. Jain SK, Mazumdar S, Subrahmanyam D 1977 Effect of phenylhydrazine on the plasma lipids of albino rats. Nuanyn-Schmiedbergs Arch Pharmaco 298:75

18. Folch J, Lees M, Sloane-Stanley GM 1957 A simple method for the isolation and purification of total lipids from animal tissues. J Biol Chem 226:497

19. Zlatkis A, Zak B, Boyle AJ 1953 A new method for the direct determination of serum cholesterol. J Lab Clin Med 41:986

20. Colton $T 1979$ Statistics in medicine. Little, Brown and Co., Boston

21. Lacko AG, Ruttenberg HL, Soloff LA 1972 On the rate of cholesterol esterification in cord blood serum. Lipids 7:426

22. Cooper RA, Gulbrandsen CL 1971 The relationship between serum lipoproteins and red cell membranes in abetalipoproteinemia: deficiency of lecithin cholesterol acyltransferase. J Lab Clin Med 78:323

23. Klimou AN, Nikiforova AA, Chistyakova AM, Magracheva EY, Anderson DW 1978 Lecithin cholesterol acyltransferase deficiency in the blood plasma of newborn. Artery 4:9

24. Andrew G, Chan G, Schiff D 1976 Lipid metabolism in the neonate 1 . The effect of intralipid infusion on plasma triglyceride and free fatty acid concentrations in the neonate. $\mathrm{J}$ Pediatr $88: 273$

25. Shennan AT, Bryan MH, Angel A 1977 The effect of gestational age of intralipid tolerance in newborn infants. J Pediatrics 91:139

26. Pereira GR, Fox WW, Stanley CA, Baker L, Schwartz JG 1980 Decreased oxygenation and hyperlipemia during intravenous fat infusions in premature infants. Pediatrics $66: 26$

27. Friedman Z, Danion A, Lamberth EL, Mann WJ 1978 Cord blood fatty acid composition in infants and in their mothers during the third trimester. $J$ Pediatr 92:461

28. Penn D, Schmidt-Somerfeld E, Wolf M 1980 Carnitine deficiency in premature infants receiving total parenteral nutrition. Early Hum Dev 4:23

29. Dhanireddy R, Hamosh M, Sivasubramaniam KW, Chowdhry P, Scanlon JW Hamosh P 1981 Post-heparin lipolytic activity and intralipid clearance in very low birth weight infants. J Pediatr 98:617

30. Levene MI 1982 Tolerance of parenteral fat in the preterm neonate. In: Wesdorp RIC, Soeters PB (ed) Clinical Nutrition '81. Churchill Livingston, New York

\title{
The Action of Dopamine upon Brown Adipose Tissue
}

\author{
G. M. MAXWELL, SILVIA CROMPTON, C. SMYTH, AND G. HARVEY \\ Department of Paediatrics, University of Adelaide, The Adelaide Children's Hospital, North Adelaide, \\ South Australia
}

\begin{abstract}
We increased the mass of interscapular brown adipose tissue in rats by dietary manipulation ("cafeteria" feeding), cold exposure, or by both. The animals were then used to determine the temperature response of the interscapular brown adipose tissue to dopamine or norepinephrine. These results, and the increase in blood glycerol values, were very similar for either catecholamine. These findings suggest that dopamine may have a role in releasing energy from brown adipose tissue similar to that of norepinephrine in the newborn infant. (Pediatr Res 19: $60-63,1985$ )
\end{abstract}

\section{Abbreviation}

BAT, brown adipose tissue

Some years ago we documented a high concentration of dopamine in the urine of human neonates (8). We postulated then that dopamine might have a homeostatic role like that of norepinephrine, which can release energy from brown adipose tissue (6). Herein we report our findings concerning the effects of dopamine upon BAT stores in the laboratory rat.

\section{MATERIALS AND METHODS}

Received April 9, 1984; accepted July 25, 1984.

Correspondence Professor G. M. Maxwell, Department of Paediatrics, University of Adelaide, Adelaide Children's Hospital, North Adelaide, South Australia 5006 .
The subjects were 32-day-old litter mate, weanling, female rats of the Porton type of the Sprague-Dawley strain. They were 